\title{
First-line cisplatin plus bolus 5- Fluorouracil combination in patients with locally advanced and metastatic esophageal cancer (Izmir Oncology Group Study)
}

\section{Lokal ileri ve metastatik özefagus kanserli hastalarda ilk hat bolus 5- Fluorourasil sisplatin kombinasyonu (İzmir Onkoloji Grubu Çalışması)}

\author{
Murat Akyol, Yüksel Küçükzeybek, Umut Varol, Ibrahim Yıldız, Suna Çokmert, İbrahim Vedat Bayoğlu, \\ Yaşar Yıldız, Lutfiye Demir, Alper Can, Ahmet Dirican, Ahmet Alacacıoğlu, Mustafa Oktay Tarhan \\ İzmir Katip Çelebi Üniversitesi Atatürk Eğitim Ve Araştırma Hastanesi,izmir
}

\section{ÖZET}

Amaç: Sitotoksik kemoterapi, lokal ileri ve metastatik özefagus kanserinin standart tedavisidir. Biz bu çalışmada lokal ileri ve metastatik özefagus skuamoz hücreli kanserde birinci basamakta sisplatin ve kısa süreli infüzyonel 5-florourasil (5-FU) kombinasyonunun yararlarını ve yan etkilerini değerlendirdik..

Yöntem: Bu çalışmada, retrospektif olarak aralık 2006 ve temmuz 2013 tarihleri arasında sisplatin ve kısa süreli infüzyonel 5-florourasil (5-FU) kombinasyonu ile tedavi edilen daha önceden tedavi almamış lokal ileri veya metastatik özefagus skuamoz hücreli kanserli hastaları değerlendirdik. Kemoterapi rejimi olarak sisplatin 75 $\mathrm{mg} / \mathrm{m} 2$ d1 (1-3-saat infuzyon), kalsiyum lökoverin $60 \mathrm{mg} / \mathrm{m} 2$ d1-2 ve 5-FU $500 \mathrm{mg} / \mathrm{m} 2$ d1-2 (15-dakika infuzyon) 14 günde bir uyguland1.

Bulgular: Hastaların 14'ü (\%51.9) erkek ve 13’ü (\%48.1) kadın olup ortanca yaş 57 (39-80) idi. ECOG performans skoru $20(\% 77)$ hastada 0 veya 1 iken diğer hastalarda 2 olarak bulundu. Tanı anında 10 hasta uzak metastaza sahipken 17 hasta lokal ileri hastalığa sahipti. Hastalar medyan 4 kür kemoterapi aldı. Tüm yanıt oranı \%44.4'tü. (8 hastada parsiyel yanıt,4 hasta komplet yanıt) ve 7 (\%25.9) hasta stabil hastalığa sahipti. Hastalık kontrol oranı \%70.3'tü. Hastaların medyan progresyonsuz sağkalımı 6.2 (\%95 CI: 5.13 7.28) ve medyan genel sağkalımı 11.1 (\%95 CI: 7.77-14.5) aydı. Hastaların \% 40.7'sinde grade 3-4 nötropeni ve \% 11.1'inde grade 3-4 trombositopeni saptandi.

Sonuç: Sisplatin ve kısa süreli infüzyonel 5-florourasil (5-FU) kombinasyonu ilaç infuzyonu için kateter gerektiren infüzyonel rejime alternative bir tedavi olarak düşünülebilir.

Anahtar Kelimeler: Özefagus kanseri, lokal ileri, metastatic, sisplatin, 5-florourasil

\begin{abstract}
Objective: Cytotoxic chemotherapy is the basic treatment for locally advanced and metastatic esophageal cancer. We evaluated the benefits and side effects of the first-line short-term infusional 5- Fluorouracil (5-FU) and cisplatin combination regimen in patients with locally advanced and metastatic esophageal squamous cell cancer. Methods: We retrospectively reviwed the untreated locally advanced or metastatic squamous cell esophageal cancer patients treated with short-term infusional 5-FU and cisplatin combination between December 2006 and july 2013. Chemotherapy regimen was administered as; cisplatin $75 \mathrm{mg} / \mathrm{m} 2$ on day 1 (1-3-h infusion), caleucovorin $60 \mathrm{mg} / \mathrm{m} 2 \mathrm{~d} 1-2$ and 5-FU $500 \mathrm{mg} / \mathrm{m} 2 \mathrm{~d} 1-2$ (15-min infusion) every 14 days.

Results: There were 14 (51.9\%) male and $13(48.1 \%)$ female patients. The median age was 57 (range, 39-80) years. Twenty patients had an Eastern Cooperative Oncology Group performance status of 0 to 1 (77\%), while the rest had PS of $2(23 \%)$. At first diagnosis, 10 patients had distant metastases and 17 patients had localized disease. In total, 27 patients were treated with a median of four cycles. The overall response rate was $44.4 \%(8$ partial responses, 4 complete responses) and 7 patients $(25.9 \%)$ had stable disease. The disease control rate was 70.3\%. Median progression free survival was 6.2 (95\% CI: 5.13 7.28) months and median overall survival was 11.1 (95\% CI: 7.77-14.5) months. Among the patients, $40.7 \%$ of them had grade $3-4$ neutropenia, $11.1 \%$ of those patients had grade 3-4 thrombocytopenia.

Conclusıon: Short-term infusional 5-FU and cisplatin combination regimen can be considered as an alternative treatment to an infusion regimen in which a catheter is necessary for the drug infusion.
\end{abstract}

Key words: Esophageal cancer, locally advanced, metastasis; cisplatin; 5- Fluorouracil 


\section{Introduction}

Esophageal cancer is among the main causes of cancer death worldwide because of its extremely aggressive nature and poor survival rate. Approximately half of the patients with localized esophageal cancer die within the first 2 years following tumor resection due to progression to metastatic disease. Cancer of the esophagus typically occurs in one of two forms; upper two-thirds is a squamous cell carcinoma (SCC) and lower one-third is an adenocarcinoma.It is assumed that there are complete differences between esophageal adenocarcinomas and squamous cell cancer, such as the treatment protocol and prognosis. $(1,2,3)$

Cytotoxic chemotherapy is the most effective treatment modality for esophageal cancer patients with metastatic disease.(4) Grunberger et al. have showed that palliative chemotherapy can prolong the survival of metastatic esophageal cancer patients, relieve their symptoms and improve their quality of life. Nevertheless, no optimizing chemotherapy regimen has been developed for either locally advanced or metastatic disease and especially for squamous cell cancer (SCC) histology.(5) Numerous single agents and combination chemotherapy regimens have been evaluated in patients with metastatic carcinoma of the esophagus and combination therapies have been shown to be superior to monotherapies. Cisplatin-based combinations are well reported to show high response rates (15\%-53\%) and median survival durations range from 3.2 to 9.8 months. Cisplatin in combination with various drugs like bleomycin, vinorelbine and etoposide were tested. $(6,7,8,9)$ However, the combination of cisplatin plus 5- Fluorouracil (5-FU) has been one of the most commonly used regimens in both metastatic and localized esophageal cancer due to its activity and wellestablished toxicity profile. Currently, cisplatin and infusional 5-FU regimen is considered to be standard therapy for the first-line treatment of metastatic esophageal cancer patients in many centers.(10,11,12) Addition of taxanes or anthracyclins to combination regimens can provide a statistically significant improvement in esophagogastric adenocancer subtype. But the efficacy of triplet regimens in squamous subtype is not clear. $(13,14)$

In particular, many studies regarding infusional 5-FU regimens in gastrointestinal and head-neck cancers showed more frequent catheter-related complications (infection and venous thrombosis).(15,16) So, we aimed to investigate the efficiency of short-term infusion of 5-FU and cisplatin combination in previously untreated patients with metastatic esophageal squamous cell cancer.

\section{Materials and Methods \\ Patients}

The data of 27 patients diagnosed with locally advanced or metastatic esophageal squamous cell cancer and presenting at the Medical Oncology Outpatient Clinic of Izmir Katip Celebi University Ataturk Training and Research Hospital between December 2006 and july 2013 were evaluated retrospectively. We included the patients treated with shortterm infusional 5-FU and cisplatin combination in previously untreated locally advanced or metastatic esophageal squamous cell cancer, because they could not be treated with the 5-day infusion due to catheterassociated problems and social issues. Other inclusion criteria were Eastern Cooperative Oncology Group (ECOG) performance score (PS) of 0 to 2 (17) and adequate hepatic, renal, and marrow function (leukocyte count > 3000/IL, absolute neutrophil count >1500/uL, platelet count $\geq 100,000 / 1 \mathrm{~L}$, total bilirubin $\leq$ 1.5 times the institutional upper limits of normal and creatinine $\leq 1.5 \quad \mathrm{mg} / \mathrm{dL}$ ). Treatment Plan

Chemotherapy regimen was administered as; cisplatin $75 \mathrm{mg} / \mathrm{m}^{2}$ on day $1(1-3-\mathrm{h}$ infusion), ca-leucovorin $60 \mathrm{mg} / \mathrm{m}^{2} \mathrm{~d} 1-\mathrm{d} 2$ and 5 -FU $500 \mathrm{mg} / \mathrm{m}^{2} \mathrm{~d} 1-\mathrm{d} 2$ (15-min infusion). Cisplatin was given with pre- and posthydration and furosemide-induced diuresis. The regimen was repeated every 14 days. Before chemotherapy, standard premedication procedures were performed. Dose modifications were made according to nadir count of previous cycles. Cisplatin dose was reduced by $25 \%$ and $5-\mathrm{FU}$ by $50 \%$ in case of leukocyte count $<1 \times 10^{9} / 1$ or platelet nadir $<5 \times 10^{9} /$ l. Cisplatin was stopped if serum creatinine $>3 \mathrm{mg} / \mathrm{dl}$ or creatinine clearance $<40$ $\mathrm{ml} / \mathrm{min}$.

Response Evaluation and Toxicity

Baseline tumor assessment was performed in all patients via abdominopelvic computed tomography (CT) and magnetic resonance imaging, and chest $\mathrm{CT}$ to rule out 
other metastases. Radiological assessment was repeated every 8-10 weeks or every four-six cycles of therapy until progressive disease (PD) or cessation of chemotherapy. If a patient's disease was in response or stable at the time of treatment withdrawal, the patient was observed every 6-8 weeks until PD.

Progression free survival (PFS) was the investigated primary endpoint, which was defined as the time from the start of first-line cisplatin plus 5-FU treatment to the first documentation of progression. First documentation of progressive disease was based on the definition of PD in the RECIST (Response Evaluation Criteria in Solid Tumors 1.1) guidelines (18) and death as a result of any cause in the absence of previously documented PD. We censored the last clinical visit data for patients that died without known progression. Response duration was measured from the day of its initial documentation until confirmed disease progression and overall survival (OS) was measured from the initiation of treatment to death or to the last follow-up assessment. Patients were evaluated for hematological and nonhematological toxicities and were graded according to the National Cancer Institute (NCI) Common Toxicity Criteria, version 3.0 (19).

\section{Statistical Analysis}

The primary objective was the activity evaluated as overall response rate (ORR) (complete + partial response). PFS and OS were calculated using the Kaplan-Meier method. The SPSS software (ver. 15.0) was used for statistical analysis. Quantitative data are presented as the means, standard errors, medians, minimums and maximums; the results of qualitative analyses are presented as frequencies and percentages.

\section{Results}

\section{Patients}

We retrospectively reviewed the data of 27 patients with a diagnosis of locally advanced or metastatic esophageal squamous cell cancer presenting. There were $14(51.9 \%)$ male and $13(48.1 \%)$ female patients. The median age was 57 (range, 39-80) years. Twenty patients had an ECOG PS of 0 to $1(77 \%)$, while the rest had PS of $2(23 \%)$. Nearly half of the patients (n:13, 48\%) had moderate differantation, 2 patients had well differantation, 9 patients had poor differantation and 3 patient could not be evaluated. At first diagnosis, 10 patients had distant metastases and 17 patients had localized disease. Primer tumor localizations were upper esophagus in $14(51.9 \%)$ patients, middle esophagus in $9(33.3 \%)$ patients and lower esophagus in $4(14.8 \%)$ patients. Patient characteristics are shown in Table 1.

Table 1. Patient characteristics and treatment details

\begin{tabular}{|c|c|c|}
\hline Clinical findings & No. of patients & $\%$ \\
\hline $\begin{array}{c}\text { Age (years) } \\
\text { Median } \\
\text { Range }\end{array}$ & $\begin{array}{c}57 \\
39-80\end{array}$ & \\
\hline $\begin{array}{c}\text { ECOG Performance st } \\
0 \\
1 \\
2\end{array}$ & $\begin{array}{c}10 \\
10 \\
6\end{array}$ & $\begin{array}{l}(38.5) \\
(38.5) \\
(23.0)\end{array}$ \\
\hline $\begin{array}{l}\text { Tumor Differantation } \\
\text { Well } \\
\text { Moderate } \\
\text { Poor }\end{array}$ & $\begin{array}{c}2 \\
13 \\
9\end{array}$ & $\begin{array}{l}(8.3) \\
(54.2) \\
(37.5)\end{array}$ \\
\hline $\begin{array}{l}\text { Primary tumor location } \\
\text { Upper } \\
\text { Middle } \\
\text { Lower }\end{array}$ & $\begin{array}{c}14 \\
9 \\
4\end{array}$ & $\begin{array}{l}(51.9) \\
(33.3) \\
(14.8)\end{array}$ \\
\hline $\begin{array}{l}\text { Stage at first diagnosis } \\
\text { Localised } \\
\text { Metastatic }\end{array}$ & $\begin{array}{l}17 \\
10\end{array}$ & $\begin{array}{l}(63.0) \\
(37.0)\end{array}$ \\
\hline $\begin{array}{l}\text { Metastatic sites } \\
\quad 0 \text { or } 1 \\
\quad \geq 2\end{array}$ & $\begin{array}{c}18 \\
9\end{array}$ & $\begin{array}{l}(66.0) \\
(33.0)\end{array}$ \\
\hline Treatment & & \\
\hline $\begin{array}{l}\text { Prior surgery } \\
\text { No surgery } \\
\text { R0 } \\
\text { R1-2 }\end{array}$ & $\begin{array}{c}13 \\
11 \\
3\end{array}$ & $\begin{array}{l}(48.1) \\
(40.8) \\
(11.1)\end{array}$ \\
\hline $\begin{array}{l}\text { Prior radiotherapy } \\
\text { No radiotherapy } \\
\text { Neoadjuvant } \\
\text { Primary definitive } \\
\text { Adjuvant }\end{array}$ & $\begin{array}{c}16 \\
5 \\
3 \\
3\end{array}$ & $\begin{array}{l}(59.3) \\
(18.5) \\
(11.1) \\
(11.1)\end{array}$ \\
\hline $\begin{array}{l}\text { Time from surgey to m } \\
\text { Median, month } \\
\text { Range }\end{array}$ & $\begin{array}{l}14.7 \\
2-70\end{array}$ & \\
\hline
\end{tabular}

ECOG PS= Eastern Cooperative Oncology Group performance status

\section{Treatment Modalities}

The median number of chemotherapy courses for the entire group was four (range, 2 
to 12). Fourteen patients had previous surgery while 11 patients had previous radiotherapy before metastatic disease. Only $3(11.1 \%)$ of 11 patients had adjuvant radiotherapy for R1-R2 resection after surgery while $5(18.5 \%)$ patients had radiotherapy as neoadjuvant treatment. None had received prior chemotherapy for metastatic disease.

\section{Response Rates and Toxicity}

The overall response rate (ORR) was 44.4\% (8 partial responses, four complete responses). Seven patients (25.9\%) had stable disease and the disease control rate was $70.3 \%$. Response rates to treatment are shown in Table 2. The most common reason for treatment withdrawal was disease progression.. The most common grade 3-4 toxicities were neutropenia. While $40.7 \%$ of the patients had grade 3-4 neutropenia, $11.1 \%$ of those patients had grade 3-4 thrombocytopenia. The most common nonhematolojic toxicities were nausea/vomiting and less commonly mucositis. There was no treatment-related death. Table 3 lists the common treatment-related toxicities.

Table 2. Objective response, clinical benefit and disease control rates

\begin{tabular}{lcc}
\hline Response & $\begin{array}{c}\text { No. of } \\
\text { patients }\end{array}$ & $\%$ \\
\hline Objective response & 12 & 44.4 \\
Complete response & 4 & 14.8 \\
Partial response & 8 & 29.6 \\
Stable disease for $\geq 3$ months & 7 & 25.9 \\
Disease control rate & 19 & 70.3 \\
\hline
\end{tabular}

Table 3. Hematologic and non-hematologic toxicity profiles.

\begin{tabular}{lllll}
\hline \multirow{2}{*}{ Toxicity } & \multicolumn{2}{c}{ Grade 1-2 } & \multicolumn{2}{c}{ Grade 3-4 } \\
\cline { 2 - 5 } & $\begin{array}{l}\text { No.of } \\
\text { patients }\end{array}$ & $(\%)$ & $\begin{array}{l}\text { No.of } \\
\text { patients }\end{array}$ & $(\%)$ \\
\hline Hematological & 20 & $(74.1)$ & 1 & $(3.7)$ \\
Anemia & 10 & $(37)$ & 11 & $(40.7)$ \\
Nötropenia & 4 & $(14.8)$ & 3 & $(11.1)$ \\
Thrombocytopenia & & & & \\
\hline Non-hematological & 9 & $(33.3)$ & 2 & $(7.4)$ \\
Mukocyt mucositis & 14 & $(51.9)$ & 3 & $(11.1)$ \\
Nause/vomiting & 3 & $(11.1)$ & 0 & $(0)$ \\
Diarrhea & & & & \\
\end{tabular}

Survival Analysis

Median follow-up was 15.0 months (range, 3-95 months). Median time from operation to the first development of metastases was 14.7 months (range, 2-70 months). Median PFS was 6.2 months (95\% CI: 5.13-7.28) and median OS was 11.1 months (95\% CI: 7.77-14.5). The PFS curve is shown in Figure 1 and the OS curve in Figure 2. By the time the data were reviewed, 22 patients $(81.5 \%)$ had died and 23 patients $(85.2 \%)$ had progressed.

Figure 1. Progression-free survival curve of the metastatic esophagus cancer patients treated with first-line cisplatin plus 5FU

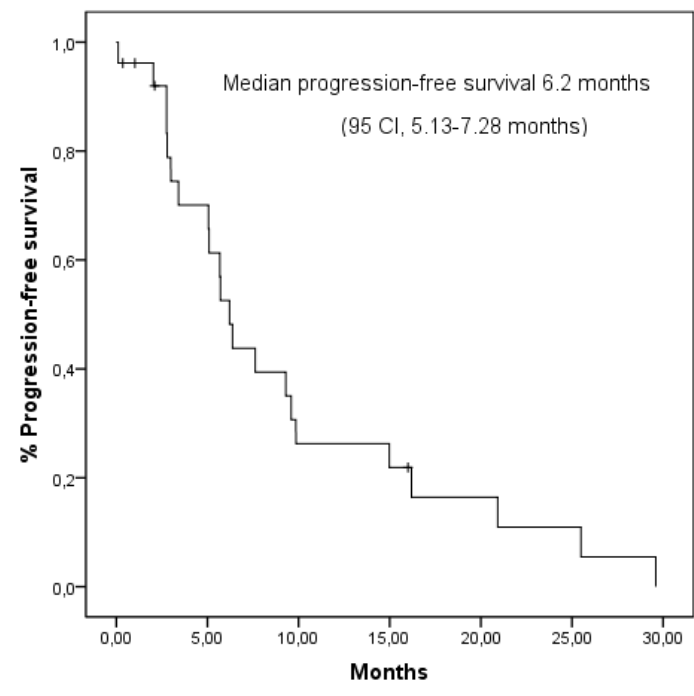

Figure 2. Overall survival curve of the metastatic esophagus cancer patients treated with first-line cisplatin plus 5-FU

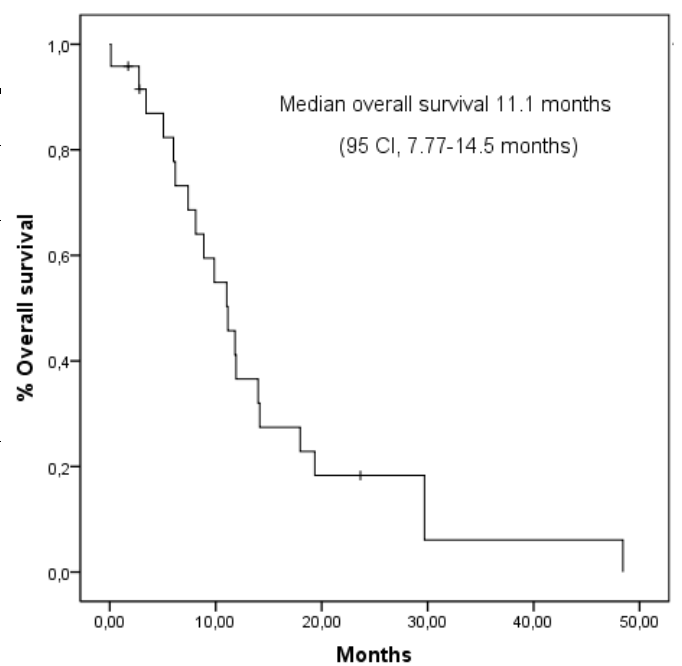

Adress for correspondence: Doç. Dr. Ahmet Alacacıŏlu , Izmir Katip Celebi University, Ataturk Training and Research Hospital, Medical Oncology, Izmir, Turkey IZMMiR - Türkiye 


\section{Discussion}

The role of chemotherapy has been poorly investigated in patients with advanced esophageal cancer. When we reviewed the literature, we found that trials relevant to chemotherapy have poor quality. Because they included small number of patients and the histologic types of esophageal cancer was not (adenocarcinoma and SCC) taken into account . $(20,21)$ Although combination chemotherapies seem superior to monotherapies, the gain in response might be counterbalanced by a decreased tolerability or an increased toxicity. Therefore, even now, the benefit of chemotherapy in patients with disseminated disease is far from being proven and the prognosis of patients with advanced esophageal carcinoma is still poor.(22)

Currently, cisplatin and 5-FU combination is considered the standart regimen for patients with esophageal carcinoma. In a phase 2 study, H.Bleiberg et al. investigated 88 patients with locally advanced or metastatic squamous cell carcinoma of the oesophagus and treated them with cisplatin $100 \mathrm{mg} / \mathrm{m}^{2}$ combined with $5-\mathrm{FU}$ at a dose of $1000 \mathrm{mg} / \mathrm{m}^{2}$ as a continuous infusion from days 1-5 (Arm A) or with cisplatin alone (Arm B) every 3 weeks. The response rate was $35 \%$ in Arm A and $19 \%$ in Arm B. The median duration of survival was 33 weeks and 28 weeks for Arm A and Arm B, respectively. Haematological and non-haematological toxicities were more frequent and more severe in Arm A. Grade 3-4 neutropenia was observed in $14 \%$ of patients and vascular trombotic events occured in 9\% patients.(22) Kies et al. and Ajani et al. have both reported high response rates of about $60 \%$ for resectable or localized tumors with cisplatin and 5-FU combination. However, lizuka et al reported a response rate of only $35.9 \%$ with the same combination for patients with metastatic, recurrent, or bulky unresectable esophageal cancer. $(23,24)$

Jacqueline et al. in a phase 3 randomized study, compared the efficacy and toxicity of cisplatin plus bolus 5-FU versus infusional 5FU as a first-line treatment in 232 patients with advanced esophageal, gastric and pancreatic cancer. Among the patients, only 38 of them were esophageal cancer while 19 had squamous cell histology. Most of the patients were gastric and pancreatic cancer. In this study, at first cycle these patients received either FP (arm A: 5-FU $800 \mathrm{mg} / \mathrm{m}^{2} / \mathrm{d}$ in continuous infusion 5 days and cisplatin 100 $\mathrm{mg} / \mathrm{m}^{2}$ on day 1 or 2 ), or FLP (arm B: LV, 100 $\mathrm{mg} / \mathrm{m}^{2} / \mathrm{d}$ in bolus 5 days, followed by $5-\mathrm{FU}$ $350 \mathrm{mg} / \mathrm{m}^{2} / \mathrm{d}$ in $1 \mathrm{~h}$ infusion 5 days and cisplatin $100 \mathrm{mg} / \mathrm{m}^{2}$ on day 1 or 2). Efficacy in terms of tumor response and survival was similar in two arms, showing an objective response rate of $18.6 \%$ in arm $\mathrm{A}$ vs. $15 \%$ in $\operatorname{arm} B$, an overall median survival of 24 weeks in $\operatorname{arm} \mathrm{A}$ vs. 24.7 in $\operatorname{arm~B~}(p=0.83)$ and a median progression-free survival of 12.4 weeks vs. 12.1 in arms A and B $(p=0.91)$, respectively. Grade 3-4 neutropenia was observed \%35.1 in arm B vs. \%33.1 in arm A (12).

In another phase II study, 30 patients with unresectable, locally advanced or metastatic squamous cell or adenocarcinoma of the esophagus used folinic acid $200 \mathrm{mg} / \mathrm{m}^{2} / \mathrm{d}, \quad 5$-FU 300 $\mathrm{mg} / \mathrm{m}^{2} / \mathrm{d}, \quad$ and cisplatin $20 \quad \mathrm{mg} / \mathrm{m}^{2} / \mathrm{d}$ intravenously for 5 days every 4 weeks. Two of 13 patients with squamous cell carcinoma had a complete response. Six other patients ( $3 \mathrm{SCC}$ ) had a partial response with a median duration of 9 months for an overall response rate of $27 \%$. Further 6 patients $(20 \%)$ had stable disease. Grade 4 neutropenia occurred in 6 patients $(20 \%)$, with 5 requiring antibiotics for associated fever. Other grade 4 toxicities were nausea and vomiting, anemia, and thrombocytopenia occurred in one each (20).

In our study, the overall response rate was $44.4 \%$ (8 partial responses, 4 complete responses). Seven patients $(25.9 \%)$ had stable disease. The disease control rate was $70.3 \%$. Median PFS was 6.2 (95\% CI: 5.13-7.28) months and median OS was 11.1 (95\% CI: 7.77-14.5) months. Among the patients, $40.7 \%$ of them had grade 3-4 neutropenia, $11.1 \%$ of those patients had grade 3-4 thrombocytopenia. According to our results and the previous reports, short-term infusional 5-FU and cisplatin combination in previously untreated locally advanced or metastatic esophageal squamous cell cancer were seem to be similar with continuous infusional 5-FU in terms of median OS and PFS. However, grade 3-4 toxicity rates were more frequent than infusional 5-FU except for grade 3-4 nonhematological adverse effects. When treatment-related toxicities of infusional and 
bolus 5-FU-containing regimens were compared in advanced-stage gastrointestinal and head-neck cancer, bolus 5-FU regimens appear to have a higher rate of hematologic toxicities, while gastrointestinal toxicities (diarrhea, vomitting, etc.) were seen less frequently. $(15,25,26)$ As a result, this combination appears to be an active and convenient regimen for advanced esophageal cancer, resulting in prolonged remission and survival in some patients.

Despite the consideration of infusional chemotherapy as standard regimen for the treatment of esopahegeal cancer, there is a main problem with these regimens. This is the neccesity for a central venous catheter and ambulatory infusion pump. Many studies regarding infusional 5-FU regimens in gastrointestinal and head-neck cancers showed more frequent catheter-related complications (infection and venous thrombosis). $(15,16)$ So, thrombosis and catheter infections are major problems with infusion regimens. Deaths due to thrombosis around the central catheter have been reported. For example, a major drawback to the ECF (Epirubicin, cisplatin, 5-FU) regimen used in advance esophagogastric adenocarcinoma is the need for a central venous line. In this randomized trial, central venous line complications occurred in 15 percent of those receiving ECF.(13)

Since this regimen carries a high risk for febrile neutropenia, it can be managed with primary prophylactic granocyte colonystimulating factor. Nevertheless, short-term infusional 5-FU and cisplatin combination regimen can be considered an alternative treatment to an infusion regimen due to similar survival outcome of the patients.

\section{Conflict of Interest: None}

\section{References}

1. Jemal A, Siegel R, Xu J, Ward E: Cancer statistics, 2010. CA Cancer J Clin, 60: 277-300, 2010.

2. Thorban S, Roder JD, Nekarda H, Funk A, Siewert JR, Pantel K: Immunocytochemical detection of disseminated tumor cells in the bone marrow of patients with esophageal carcinoma, 88: 1222-1227, 1996.
3. Thrift AP, Pandeya N, Whiteman DC: Current status and future perspectives on the etiology of esophageal adenocarcinoma. Front Oncol, 2: 11, 2012.

4. Leichman L, Berry BT: Experience with cisplatin in treatment regimens for esophageal cancer, 18: 64-72, 1991.

5. Grünberger B, Raderer M, Schmidinger M, Hejna M: Palliative chemotherapy for recurrent and metastatic esophageal cancer. Anticancer Res, 27: 27052714, 2007.

6. Kelsen D, Hilaris B, Coonley C, Chapman R, Lesser M, Dukeman M, Heelan R, Bains M: Cisplatin, vindesine, and bleomycin chemotherapy of local-regional and advanced esophageal carcinoma. Am J Med, 75: 645$652,1983$.

7. Dinwoodie WR, Bartolucci AA, Lyman GH, VelezGarcia E, Martelo OJ, Sarma PR: Phase II evaluation of cisplatin, bleomycin, and vindesine in advanced squamous cell carcinoma of the esophagus. a Southeastern Cancer Study Group Trial. Cancer Treat Rep, 70: 267-270, 1986.

8. Spiridonidis CH, Laufman LR, Jones JJ, Gray DJ, Cho CC, Young DC: A phase II evaluation of high dose cisplatin and etoposide in patients with advanced esophageal adenocarcinoma. Cancer, 78: 2070-2077, 1996.

9. Conroy T, Etienne PL, Adenis A, Ducreux M, Paillot

B, Oliveira J, Seitz JF, Francois E, Van Cutsem

E, Wagener DJ, Kohser F, Daamen S, Praet M, Gorlia T,Baron B, Wils J: European Organisation for Research and Treatment of Cancer Gastrointestinal Tract Cancer Cooperative Group. Vinorelbine and cisplatin in metastatic squamous cell carcinoma of the oesophagus: response, toxicity, quality of life and survival. Ann Oncol, 13: 721, 2002.

10. Etienne MC, Bernard S, Fischel JL, Formento P, Gioanni J,Santini J, Demard F, Schneider M and Milano G: Dose reduction without loss of efficacy for 5fluorouracil and cisplatin combined with folinic acid. In vitro study on human head and neck carcinoma cell lines. Br J Cancer, 63: 372-377, 1991.

11. Lacave AJ, Baron FJ, Anton LM, Estrada E, De Sande LM,Palacio I, Esteban E, Gracia JM, Buesa JM, Fernandez OA: Combination chemotherapy with cisplatin and 5-fluorouracil 5-day infusion in the therapy of 
advanced gastric cancer: a phase II trial. Ann Oncol, 2: 751-754, 1991.

12. Duffour J, Bouché O, Rougier P, Milan C, Bedenne L, Seitz JF, Buecher B, Legoux JL, Ducreux M, Vetter D, Raoul JL,François E, Ychou M: Safety of cisplatin combined with continuous 5-FU versus bolus 5-FU and leucovorin, in metastatic gastrointestinal cancer. Anticancer Res, 26: 3877-3883, 2006.

13. Webb A, Cunningham D, Scarffe JH, Harper P, Norman A, Joffe JK, Hughes M, Mansi J, Findlay M, Hill A, Oates J, Nicolson M, Hickish T, O'Brien M, Iveson T, Watson M, Underhill C, Wardley A, Meehan M: Randomized trial comparing epirubicin, cisplatin, and fluorouracil versus fluorouracil, doxorubicin, and methotrexate in advanced esophagogastric cancer. J Clin Oncol, 15: 261, 1997.

14. Ajani JA, Fodor MB, Tjulandin SA, Moiseyenko VM, Chao Y, Cabral Filho S, Majlis A, Assadourian S, Van Cutsem E: Phase II multi-institutional randomized trial of docetaxel plus cisplatin with or without fluorouracil in patients with untreated, advanced gastric, or gastroesophageal adenocarcinoma. J Clin Oncol, 23: 5660-5667, 2005.

15. Hitt R, Paz-Ares L, Brandáriz A, Castellano D, Peña C, Millán JM, Calvo F, Ortiz de Urbina D, López E, Alvarez-Vicent JJ, Cortés-Funes H: Induction chemotherapy with paclitaxel, cisplatin and 5-fluorouracil for squamous cell carcinoma of the head and neck: longterm results of a phase II trial._Ann Oncol, 13: 1665$1673,2002$.

16. Hansen RM, Ryan L, Anderson T, Krzywda B, Quebbeman E, Benson A 3rd, Haller DG, Tormey DC: Phase III study of bolus versus infusion fluorouracil with or without cisplatin in advanced colorectal cancer. J Natl Cancer Inst, 15; 88: 668-674, 1996.

17. Oken MM, Creech RH, Tormey DC, Horton J, Davis TE, McFadden ET, Carbone PP: Toxicity and response criteria of the Eastern Cooperative Oncology Group. Am J Clin Oncol, 6: 649-655, 1982.

18. Eisenhauer EA, Therasse P, Bogaerts J, Schwartz LH, Sargent D, Ford R, Dancey J, Arbuck S, Gwyther S, Mooney M, Rubinstein L, Shankar L, Dodd L, Kaplan R, Lacombe D, Verweij J: New response evaluation criteria in solid tumours: revised RECIST guideline (version
19. Trotti A, Colevas AD, Setser A, Rusch V, Jaques D, Budach V, Langer C, Murphy B, Cumberlin R, Coleman CN, Rubin P: CTCAE v3.0: development of a comprehensive grading system for the adverse effects of cancer treatment. Semin Radiat Oncol, 13: 176-181, 2003.

20. Warner E, Jensen JL, Cripps C, Khoo KE, Goel R, Kerr IA, Bjarnason GA, Fields AL, Hrincu A: Outpatient 5-fluorouracil, folinic acid and cisplatin in patients with advanced esophageal carcinoma. Acta Oncol, 38: 255-259, 1999.

21. Ajani JA: Contribution of chemotherapy in the treatment of carcinoma of the esophagus: Results and commentary. Semin Oncol, 21, 474-482, 1994.

22. Bleiberg H, Conroy T, Paillot B, Lacave AJ, Blijham G, Jacob JH, Bedenne L, Namer M, De Besi P, Gay F, Collette L,Sahmoud T: Randomised phase II study of cisplatin and 5-fluorouracil (5-FU) versus cisplatin alone in advanced squamous cell oesophageal cancer. Eur J Cancer, 33: 1216-1220, 1997.

23. Kies MS, Rosen ST, Tsang TK, Shetty R, Schneider PA, Wallemark CB, Shields TW: Cisplatin and 5fluorouracil in the primary management of squamous esophageal cancer. Cancer, 60: 2156-2160, 1987.

24. Ajani JA, Ryan B, Rich TA, McMurtrey M, Roth JA, DeCaro L, Levin B, Mountain C. Prolonged chemotherapy for localised squamous carcinoma of the oesophagus. Eur J Cancer, 28: 880-884, 1992.

25. Jeong J, Jeung HC, Rha SY, Im CK, Shin SJ, Ahn JB, Noh SH, Roh JK, Chung HC: Phase II study of combination chemotherapy of 5-fluorouracil, low-dose leucovorin, and oxaliplatin (FLOX regimen) in pretreated advanced gastric cancer. Ann Oncol, 19: 1135-1140, 2008.

26. Pfister DG, Bajorin D, Motzger R, et al: Cisplatin, fluorouracil, and leucovorin. Increased toxicity without improved response in squamous cell head and neck cancer. Arch Otolayngol Head Neck Surg, 120: 89-95, 1994.

1.1). Eur J Cancer, 45: 228-247, 2009.

Adress for correspondence: Doç. Dr. Ahmet Alacacıŏlu , Izmir Katip Celebi University, Ataturk Training and Research Hospital, Medical Oncology, Izmir, Turkey IZZMiR - Türkiye e-mali: dralacacioglu@gmail.com

Available at www.actaoncologicaturcica.com

Copyright @ Ankara Onkoloji Hastanesi 